\title{
New species of Hymenoptera associated with galls on Calliandra brevipes Benth. (Fabaceae, Mimosoidea) in Brazil
}

\author{
Angélica M. Penteado-Dias ${ }^{1} \&$ Fabrício M. de Carvalho²
}

1Departamento de Ecologia e Biologia Evolutiva. Universidade Federal de São Carlos. Caixa Postal 676, 13565-905 São Carlos-SP, Brasil.
angelica@ufscar.br
${ }^{2}$ Universidade Federal de Juiz-de-Fora, Campus Universitário, s/ no. Martelos, 36036-330 Juiz de Fora-MG, Brasil. ffrabicio@yahoo.com.br

\begin{abstract}
New species of Hymenoptera associated with galls on Calliandra brevipes Benth. (Fabaceae, Mimosoidea). Four species of Hymenoptera: Tanaostigmodes ringueleti (Brèthes, 1924), T. mecanga sp.nov. (Chalcidoidea, Tanaostigmatidae), Allorhogas taua sp. nov. (Braconidae, Doryctinae) and Eurytoma sp. (Chalcidoidea, Eurytomidae) were reared from two different types of galls of Calliandra brevipes Benth. (Fabaceae, Mimosoidea) in Juiz-de-Fora, Minas Gerais State, Brazil. The two Tanaostigmatidae species are probably the gall inducers; the Braconidae species probably is phytophagous inquiline in round gall type. The two new species are described and illustrated, including their immature stages.
\end{abstract}

KEYWORDS. Bionomy; Brazil; morphology; phytophagous; taxonomy.

RESUMO. Novas espécies de Hymenoptera associadas a galhas de Calliandra brevipes Benth. (Fabaceae, Mimosoidea). Quatro espécies de Hymenoptera: Tanaostigmodes ringueleti (Brèthes, 1924), T. mecanga sp. nov. (Chalcidoidea, Tanaostigmatidae), Allorhogas taua sp. nov. (Braconidae, Doryctinae) e Eurytoma sp. foram obtidas de dois diferentes tipos de galhas de Calliandra brevipes Benth. (Fabaceae, Mimosoidea) em Juiz-de-Fora, MG, Brasil. As duas espécies de Tanaostigmatidae são os prováveis indutores das galhas; a espécie de Braconidae, provavelmente é um inquilino fitófago das galhas globosas. Estas duas novas espécies são descritas e ilustradas, incluindo os seus estágios imaturos.

PALAVRAS-CHAVE. Bionomia; Brasil; fitófagos; morfologia; taxonomia.

Calliandra brevipes Benth. is an arborescent, evergreen shrub with finely dividided leaves and clusters of red powderpuff flowers (Figs. 1, 2). It is a native plant in South America, but has been introduced into many tropical and subtropical places in the world (Lorenzi \& Souza 1999). In 2004 we reared four different species of Hymenoptera from the stem and leaf galls of this plant. Specimens of Tanaostigmodes ringueleti and Allorhogas taua sp. nov. emerged only from the round stem galls; specimens of T. mecanga $\mathbf{s p . ~ n o v . ~ e m e r g e d ~ o n l y ~}$ from the oval leaf galls.

The genus Allorhogas belongs to the braconid subfamily Doryctinae, and is one of the largest genera in the Neotropical Region. Most Doryctinae species are ectoparasitoids, which usually attack wood-boring and bark-mining Coleoptera larvae, but several cases of phytophagy have been noticed (Marsh 1997). Macedo and Monteiro (1989) recorded the first case of phytophagy among the Braconidae: Allorhogas dyspistus Marsh, 1991 on Pithecellobium tortum Martius (Fabaceae). Marsh et al. (2000) presented five species of Allorhogas reared from plant seeds or galls in Brazil and Marsh (2002) described 15 new species from Costa Rica. The phytophagous habits of species in this genus make a further extensive study of the biology and taxonomy very intriguing (Marsh 2002).
Tanaostigmatidae is a small group of chalcid wasps with about 94 species in nine genera, five from the New World. They are predominantly phytophagous in habit and associated with galls, in most cases as the presumed gall-formers (LaSalle 1987). There are many records of species reared from galls, however very few detailed life cycle are known for this family. Preferred host plants for tanaostigmatids are trees and shrubs of Fabaceae, although species have been reared from galls on Polygonaceae, Rhamnaceae and Myrtaceae and collected on several other families. LaSalle (1987) recorded Tanaostigmodes ringueleti on galls of Calliandra bicolor and $C$. brevipes (= C. selloi); T. fisheri on galls of Calliandra californica; Perioto \& Lara (2005) recorded and described T. brasilianus and $T$. calliandrae on galls of $C$. dysantha from central Brazil.

According to LaSalle (1987) Tanaostigmodes is characterized by the lack of synapomorphies used to define the other four genera. Certain characteristics used to define the other genera are occasionally found in Tanaostigmodes (e.g. large setiferous punctures, all funicular segments longer than wide), but never in the same combination as found in other genera. Tanaostigmodes is the largest and most poorly defined of the tanaostigmatid genera. It is divided into twenty species groups, eight of them containing a single species. 
Following LaSalle (1987) and Perioto \& Lara (2005) we have found two tanaostigmatid species running to the tychii species group, one of them with the fore wing hyaline with a contrasting dark brown area on the middle area.

The new species of the genera Tanaostigmodes and Allorhogas are described in order to provide names for further biological studies.

\section{MATERIALAND METHODS}

The periodically collected samples of plants with developed galls were maintained in plastic containers with plastic lids. The emerging wasps were sorted by species and voucher specimens were preserved for description. After the rearing period, unexited galls were dissected and gall contents were recorded. The Tanaostigmatidae specimens were identified using the key presented in LaSalle (1987) and Perioto \& Lara (2005); for the Doryctinae we used Marsh (1991), Marsh et al. (2000); Marsh (2002). The holotypes of T. brasilianus Perioto \& Lara, 2005 and T. calliandrae Perioto \& Lara, 2005 were examined.

The wasps, plant and galls are illustrated by photos and drawings. The structure of the Braconidae larvae used the nomenclature presented in Capek (1970). The insects obtained and samples of the plants are deposited in the collection of the Departamento de Ecologia e Biologia Evolutiva da Universidade Federal de São Carlos, São Carlos, SP, Brazil (DCBU) and the Museu de Zoologia da Universidade de São Paulo, São Paulo, SP, Brazil.

\section{RESULTS ANDDISCUSSION}

The round multi-chambered stem galls on Calliandra brevipes are $6.0-10.0 \mathrm{~mm}$ in diameter (Figs. 3, 4 ) whereas the oval leaflet galls are $6.0 \mathrm{~mm}$ long with one or two chambers (Figs. 5, 8). Adults of Hymenoptera emerged from those galls (Table I).

The two Tanaostigmatidae species are probably the gall inducer; the Braconidae species probably is phytophagous inquiline in the round gall type.

Dissection of one oval leaf gall revealed only few (one or two) larvae and pupae (Fig. 8) of T. mecanga or of A. taua $\mathbf{s p .}$ nov., but only one round stem gall produced more than 130 larvae of different ages and pupae of Tanaostigmodes ringueleti and some larvae or pupae of A. taua sp. nov. Smaller larvae appeared near the surface of round galls, whereas larger ones were found at the bottom of the gall. Adults of Eurytoma sp. also emerged from the round stem galls and their larvae were found as ectoparasitoid on the braconid Allorhogas larvae. Eurytoma includes species with wide distribution and with several host groups: Coleoptera, Diptera, Homoptera, Hymenoptera and Araneae (Hanson 1995).
Allorhogas taua sp. nov. Penteado-Dias

(Figs. 6, 9-12, 25, 26, 30)

Holotype female. Body honey yellow; legs yellow; flagellum light brown; wings hyaline; fore wing veins $\mathrm{C}+\mathrm{Sc}+\mathrm{R}$ and stigma brown, rest of veins and hind wing veins light brown. Body length: $3.50-3.70 \mathrm{~mm}$.

Head: antenna with 26 flagellomeres; face rugulosecoriaceous (Fig. 9); vertex coriaceous; temple coriaceous; malar space $0.33 \mathrm{x}$ eye height; oral opening small, circular, diameter equal to basal width of mandible; ocellus-ocular distance $4.0 \mathrm{x}$ longer the diameter of lateral ocellus; occipital carina distinct meeting hypostomal carina.

Mesosoma: pronotum weakly rugulose-coriaceous (Figs. $10,11)$, laterally with deep median scrobiculate groove bordered ventrally by carina; mesonotum sharply declivous anteriorly, mesoscutum and scutellum coriaceous, middle lobe with median scrobiculate groove extending to anterior edge of mesonotum; notauli distinctly scrobiculate, meeting in large rugose area before the scutellum; scutellar furrow with four cross carinae; mesopleuron coriaceous, sternaulus deep and smooth or weakly scrobiculate; propodeum rugose, with two basolateral semicircular rugulose-coriaceous areas enclosed by carinae, apical area above metasoma insertion usually smooth, enclosed by carina.

Legs: fore tibia with scattered row of 15-20 stout spines on anterior edge; hind coxa with distinct baso-lateral tubercle.

Wings (Fig. 30): fore wing vein $r$ about $0.75 \mathrm{x}$ length of $3 R S a$ vein, $m$-cu interstitial with $2 R S$, first sub-discal cell open, vein $2 \mathrm{cu}-\mathrm{a}$ absent; hind wing vein $\mathrm{M}+\mathrm{CU}$ shorter in length to $1 \mathrm{M}$, vein $\mathrm{m}$-cu curved slightly toward wing apex.

Metasoma (Fig. 12): first tergum longitudinally costaterugulose, wider at apex than long, medially with two strong longitudinal carinae setting off raised median area and connected at base by distinct cross carina; second and third terga shorter than rest of terga combined, longitudinally costate on basal 2/3, remainder coriaceous, groove between second and third terga weak; ovipositor as long as metasoma.

Male: essentially as in female; antennae with 22 flagellomeres; femora swollen.

Larvae: length $3.0 \mathrm{~mm}$; whitish, cephalic structures light brown (Fig. 25): labial sclerite longitudinally oval; dorsal end of the pleurostoma confluent with the epistomal arch; hypostoma absent; mandibles indistinct; labial and maxillary palps as papillae; structure of skin as Fig. 26.

Reared from round stem and ovoid leaf galls on Calliandra brevipes (Fabaceae, Mimosoidea).

Material examined. Holotype female: BRASIL, Minas Gerais, Juizde-Fora, April 2004, F. M. de Carvalho col. (DCBU). Paratypes, same data of holotype: 15 females, 11 males (DCBU, MZUSP).

Etymology. Tupy language, taua = yellow; in reference to general color of the body. 

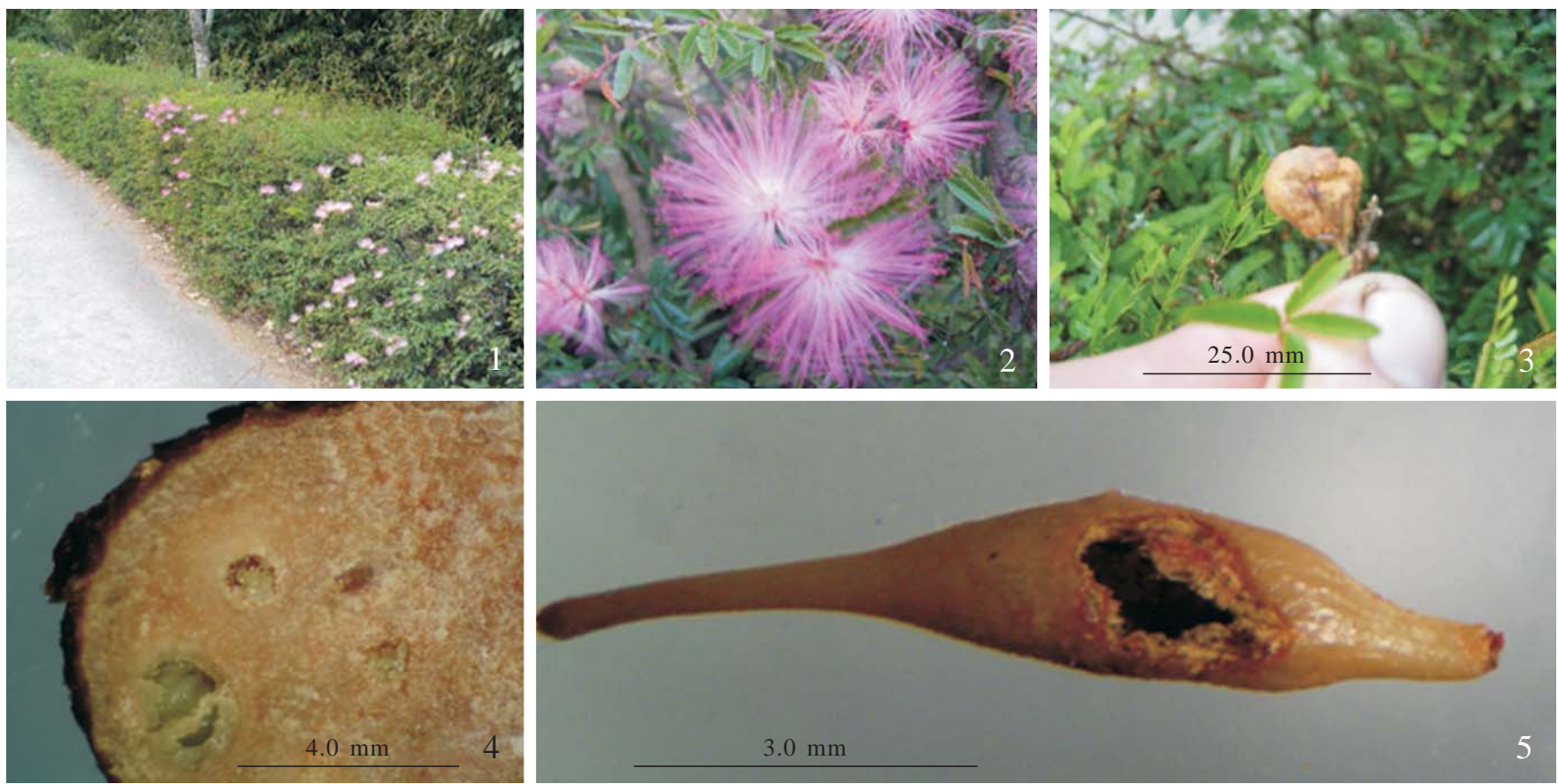

Figs. 1-5. Calliandra brevipes. 1, 2, general aspect; 3, 4, round gall; 5, ovoid gall.

This species is recognizable by the following characters: the second and third metasomal terga combined being shorter than the remainder of the terga combined; the ovipositor as long as the metasoma; the ocellus-ocular distance four times the diameter of lateral ocellus; fore wing vein $r$ as long as or shorter than vein 3RSa. Allorhogas taua $\mathbf{s p . ~ n o v . ~ i s ~ v e r y ~ s i m i l a r ~}$ to A. spermaphagus Marsh (Marsh et al. 2000), but distinct of this species by the following characters: antenna with $22-28$ antennomeres (29-30 in A. spermaphagus); fore wing vein $\mathrm{r}$ $0.75 \mathrm{x}$ the length of $3 \mathrm{RSa}$ (Fig. 30) (r equal to vein RSa in $A$. spermaphagus); vein $\mathrm{M}+\mathrm{CU}$ shorter than $1 \mathrm{M}$ (almost equal in A. spermaphagus); vertex behind the ocellus only coriaceous (often rugulose in A. spermaphagus); ovipositor as long as metasoma (about $2 / 3$ the length of metasoma in $A$. spermaphagus); ocellus-ocular distance 4.0 the diameter of lateral ocellus (ocellus-ocular distance twice the diameter of lateral ocellus in A. spermaphagus); scutellar sulcus with four or five cross carinae (three cross carinae in A. spermaphagus).

Tanaostigmodes ringueleti (Brèthes, 1924) (Figs. 13-18, 27, 28, 31)

Female. Length $1.8 \mathrm{~mm}$. General color black, scape light yellow, pedicel and flagellum dark brown; legs dark brown with apex of fore tibia and tarsus light yellow; median and hind tibiae and tarsi light yellow; tegula black.

Head (Fig. 13) as wide as high; lateral ocellus usually slightly closer to median ocellus than to eye margin; distance from eye
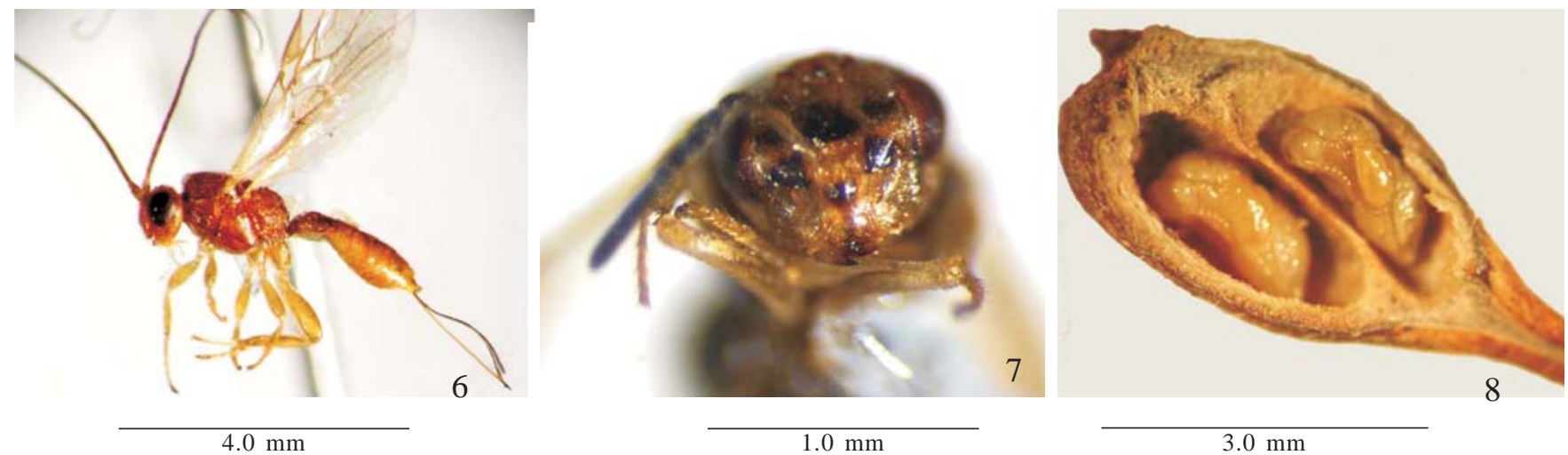

Figs. 6-8. Allorhogas taua sp. nov., female, 6, habitus. Tanaostigmodes mecanga sp. nov., female, 7, head (frontal view); 8, pupae in the gall. 

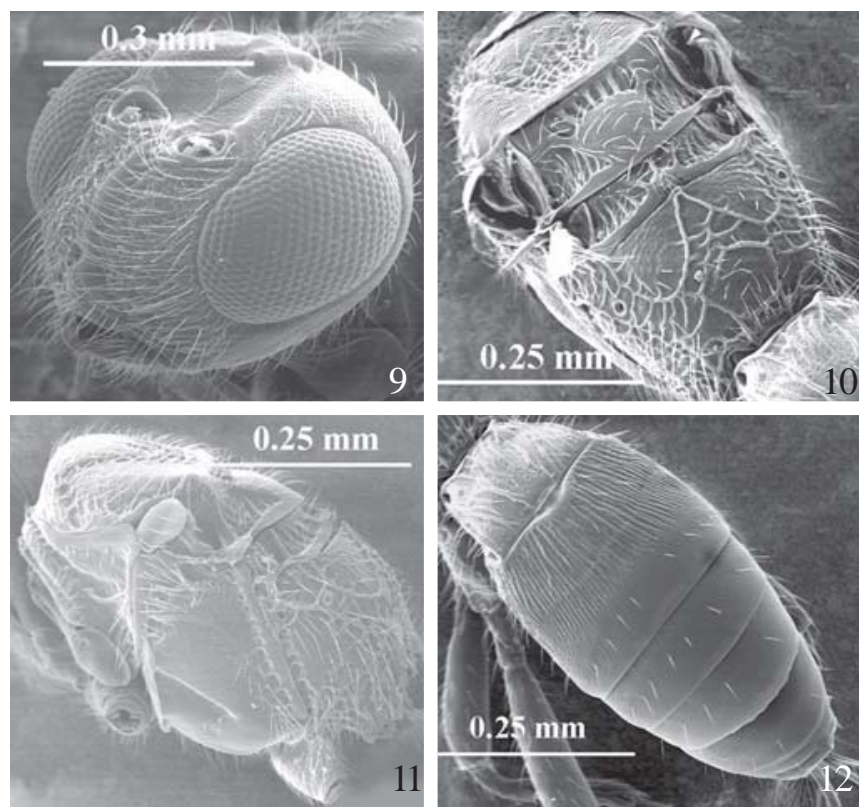

Figs. 9-12. Allorhogas taua sp. nov. female. 9, head; 10,11, mesosoma; 12, metasoma.

margin is $1.2 x$ its diameter. Face with setae; scrobal impression smooth with inter-antennae projection small, sub-ocular sulcus present, complete. Antenna with 11 flagellomeres (Fig. 14); scape $4.5 x$ longer than wide, with flattened ventral expansion; pedicel 1.0x longer than wide; funicular segments decreasing in length distally. Club 3 segmented ,1.2x longer than wide. Elongate placodeal sensilla present on all flagellomeres. Mesosoma: notauli (Fig. 15) extremely narrow, very difficult to see, complete to posterior margin of mesoscutum meeting before reaching posterior margin. Frons and face rugose with minute setiferous punctuation; occiput, gena, mesopleurum (Fig. 16) strigated and smooth ventrally. Propodeum and metasoma (Fig. 17) smooth. Wings hyaline, veins light brown, marginal fringe past the apex of wing; basal cell with 50 setae; length of costal cell $2.5 \mathrm{x}$ the marginal vein; marginal vein $1.3 \mathrm{x}$ the post-marginal vein; marginal vein $1.1 \mathrm{x}$ the stigmal vein; post-marginal vein 0.8 the stigmal vein (Fig. 31).

Male (Fig.18): length $1.0 \mathrm{~mm}$. Fore leg only with coxa black, trochanter, femur, tibia and tarsus light yellow. First flagellomere of medium size; second and third longer; fourth half of length of the second or third; first to fourth with long rami; fifth and sixth only dilated, with dorsal projections; club 3 segmented.

Hymenopteriform larva maggot-like (Fig. 27), $3.0 \mathrm{~mm}$ long, with whitish and smooth skin; head hypognathous partially retracted into the thorax, mandibles sclerotized slightly curved terminated in two apical teeth (Fig. 28); dorsal articular process of mandible prominent; remainder the body has 13 visible segments; spiracles present on the meso and metathorax and on the first eight abdominal segments. Setae well-developed present on the head and body. Pupa exarate, not protected by any special cocoon; initially yellowish, becoming darker later. The adult chews a hole in the surface of gall to emerge.
Table I. Number of specimens reared from galls on Calliandra brevipes Benth.(Fabaceae) collected at Juiz de Fora, MG, Brazil.

\begin{tabular}{lcc}
\hline Parasitoid species & $\begin{array}{c}\text { Number } \\
\text { individual on } \\
\text { round stem galls }\end{array}$ & $\begin{array}{c}\text { Number } \\
\text { individual on } \\
\text { ovoid leaf galls }\end{array}$ \\
\hline $\begin{array}{l}\text { Allorhogas taua sp. nov. } \\
\text { Tanaostigmodes ringueleti } \\
\text { (Brèthes, 1924) }\end{array}$ & 27 & 02 \\
$\begin{array}{l}\text { Tanaostigmodes mecanga } \\
\text { sp. nov. }\end{array}$ & 0 & 00 \\
$\begin{array}{l}\text { Eurytoma } \text { sp. } \\
\text { Total }\end{array}$ & 27 & 51 \\
& 374 & 04 \\
\hline
\end{tabular}

Collected from round stem galls on Calliandra brevipes (Fabaceae, Mimosoidea).

Material examined: 21 females, 10 males BRASIL, Minas Gerais, Juiz-de-Fora, April, 2004, F. Medeiros de Carvalho col. (DCBU, MZUSP).

\section{Tanaostigmodes mecanga sp. nov.} (Figs. 7, 8, 19-24; 29, 32)

Holotype female: length $2.5 \mathrm{~mm}$. General color brown to
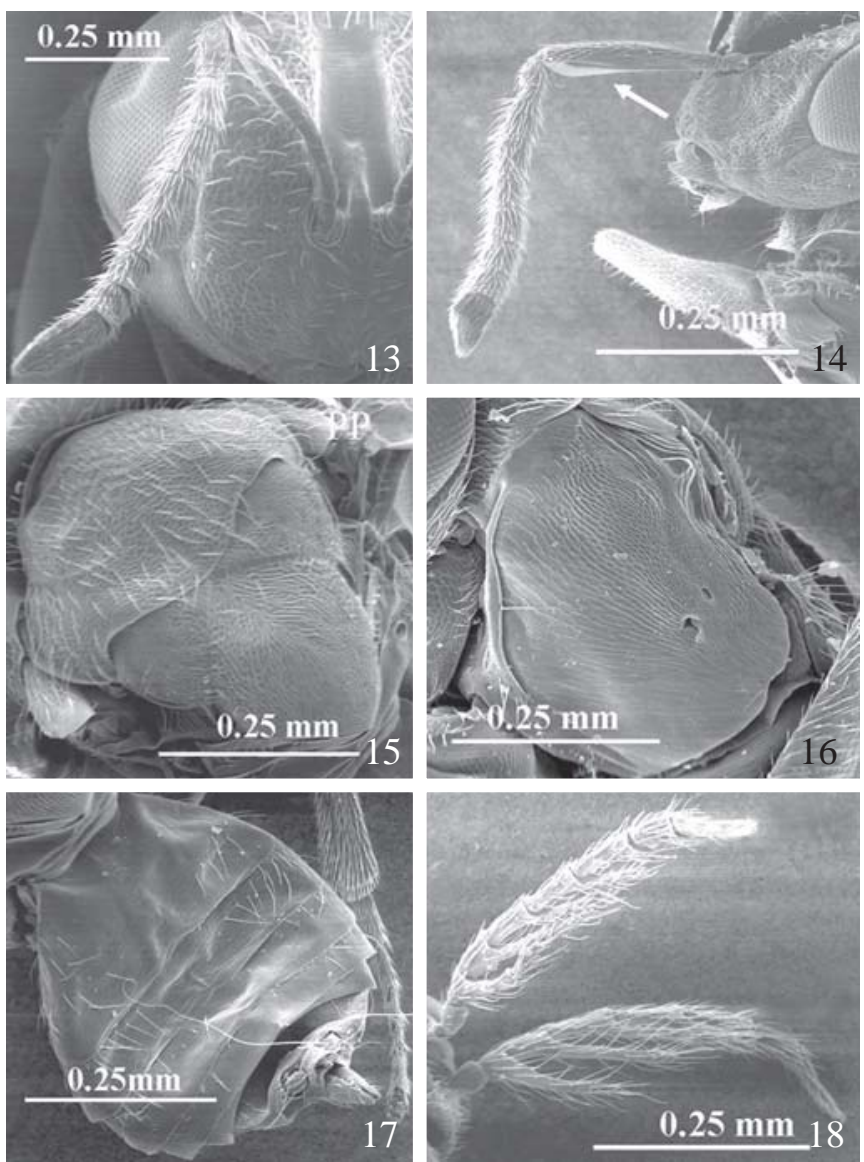

Figs. 13-18. Tanaostigmodes ringueleti, female. 13, head; 14, antenna; 15, mesosoma (dorsal view, $\mathrm{PP}=$ prepectum); 16, mesopleurum; 17 , metasoma. Tanaostigmodes ringueleti, male; 18, antennae. 

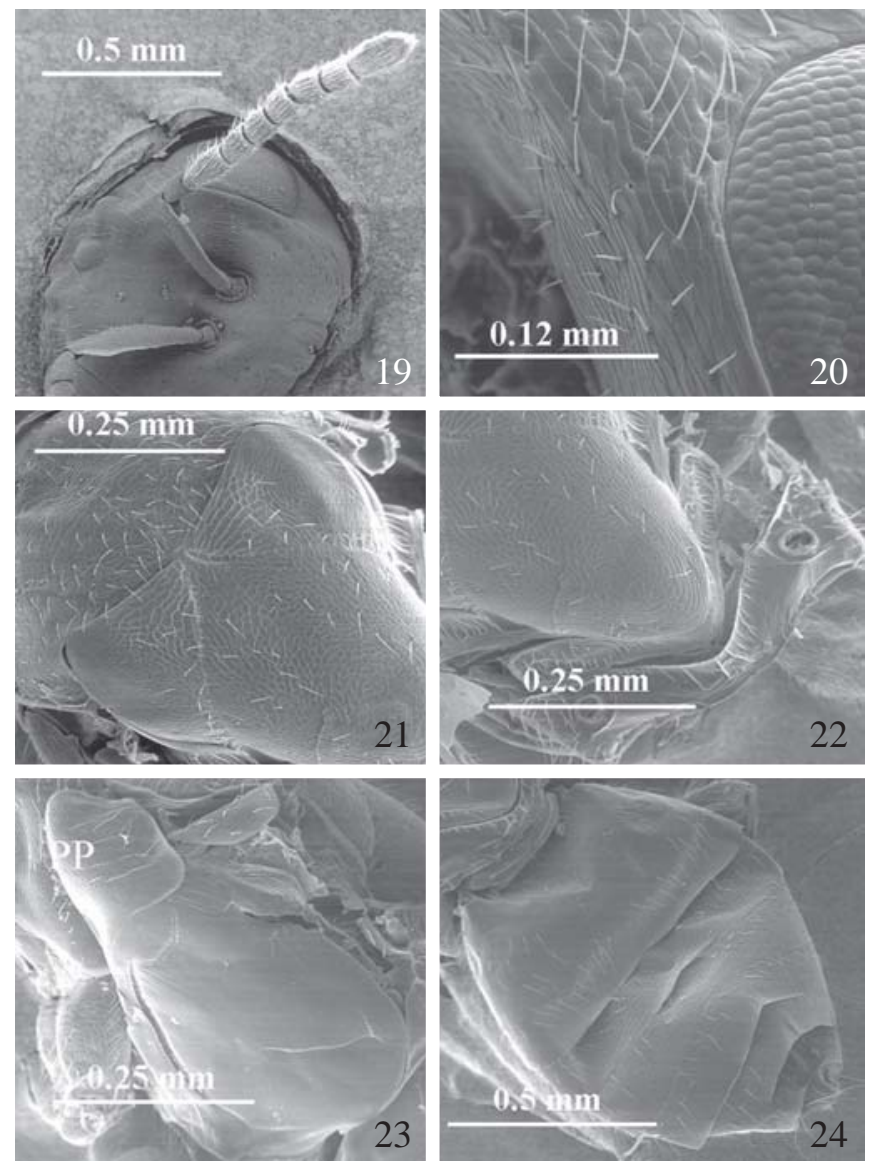

Figs. 19-24. Tanaostigmodes mecanga sp. nov., female. 19, head; 20, gena; 21, 22, mesosoma (dorsal view); 23, mesopleurum (PP=prepectum); 24, metasoma.

dark brown, legs light yellow; eyes red; mid and hind coxae infumated, head (Fig. 7) yellow with brown marks ventral to toruli, on scrobe and at internal margin of eye; scape yellow with dorsal part infumated as well the pedicel; flagellum black; tegula light yellow with apex infumated; mesosoma light brown with dark marks; propodeum and metasoma dark brown. Wings hyaline, with large spot light brown on its median area; veins light brown.

Head (Figs. 7, 19) 1.2x wider than high. Lateral ocellus slightly closer to median ocellus than to eye margin; distance from eye margin is $1.2 x$ its diameter, scrobal impression smooth, inter-antennae projection small, sub-ocular sulcus absent. Frons and face, occiput and gena (Fig. 20) coriaceous with fine punctuation; vertex rugose. Antenna with scape 4.0 longer than wide, with short flattened ventral expansion, pedicel $1.1 \mathrm{x}$ longer than wide, funicular segments decreasing in length distally, club $1.2 x$ longer than wide, with 3-segments.

Mesonotum coriaceous with gross punctuation (Figs. 21, 22); mesopleurum smooth (Fig. 23); propodeum and anterior margin of first tergite smooth; remainder tergites coriaceous (Fig. 24). Notauli extremely fine, very difficult to see, complete to posterior margin of mesoscutum meeting before reaching posterior margin. Propodeum glabrate medially with several longitudinal carinae.

Wings with marginal fringe extending past apex of wing (Fig. 32); basal cell with near 22 setae; length of costal cell 3.2x the marginal vein; marginal vein $1.6 x$ the post-marginal vein; marginal vein $1.2 \mathrm{x}$ the stigmal vein and post-marginal vein $0.7 \mathrm{x}$ the stigmal vein.

Male: unknown

Collected from oval leaf galls (Figs. 5, 8) on Calliandra brevipes (Fabaceae, Mimosoidea).

Hymenopteriform larva, $5.0 \mathrm{~mm}$ in length; skin whitish smooth; mandibles light brown with three apical teeth (Fig. 29); distinct head and thoracic segments with some long hairs as well the other segments. Pupa similar to the T. ringueleti.

Material examined: Holotype female, BRASIL, Minas Gerais, Juiz de Fora, April 2004, F. Medeiros de Carvalho col. (DCBU). Paratypes, 50 females, same data as holotype (DCBU, MZUSP).

Etymology. Tupy language: mecang $a=$ masked, in reference to black markings on yellow face.

Females of T. mecanga sp. nov. are distinct from other species of Tanaostigmodes by body brown, head yellow, face may have dark brown markings ventral to toruli and at internal margin of eye; inter-antennal projection present, small; notauli complete, sub-ocular sulcus absent, first flagellomere longer

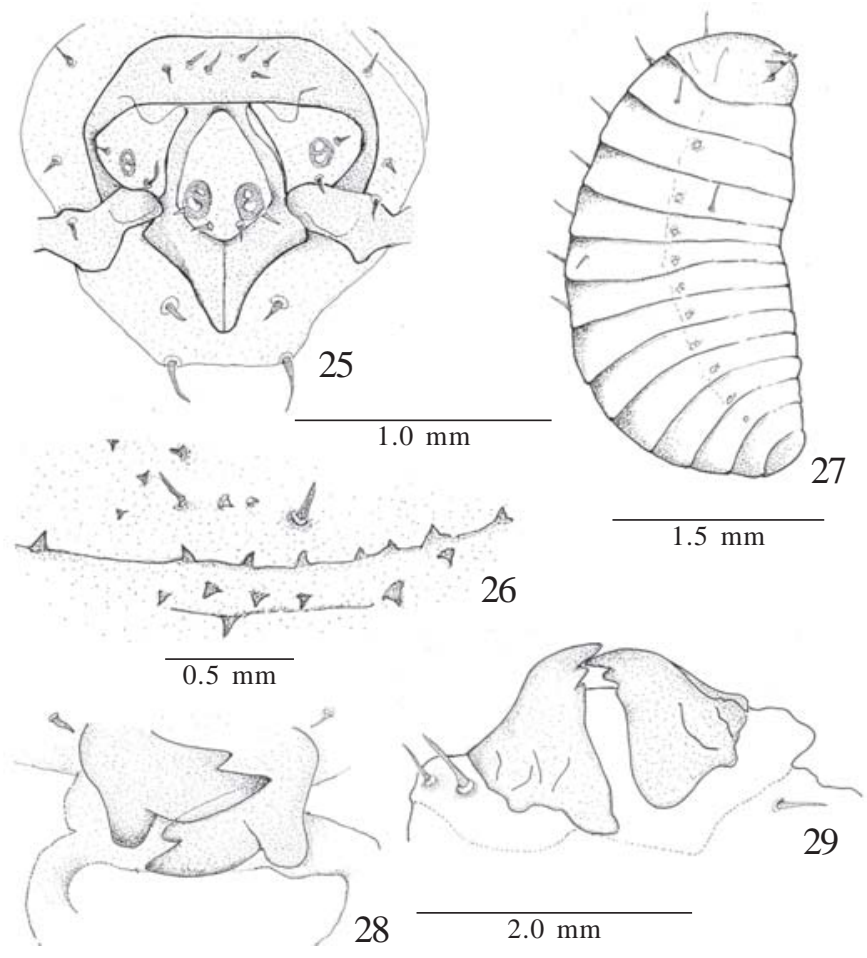

Figs. 25-29. Allorhogas taua sp. nov., 25, larva cephalic structures; 26, larva skin. Tanaostigmodes ringueleti, 27, mature larva; 28, mature larva mandibles. Tanaostigmodes mecanga sp. nov. 29, mature larva mandibles. 

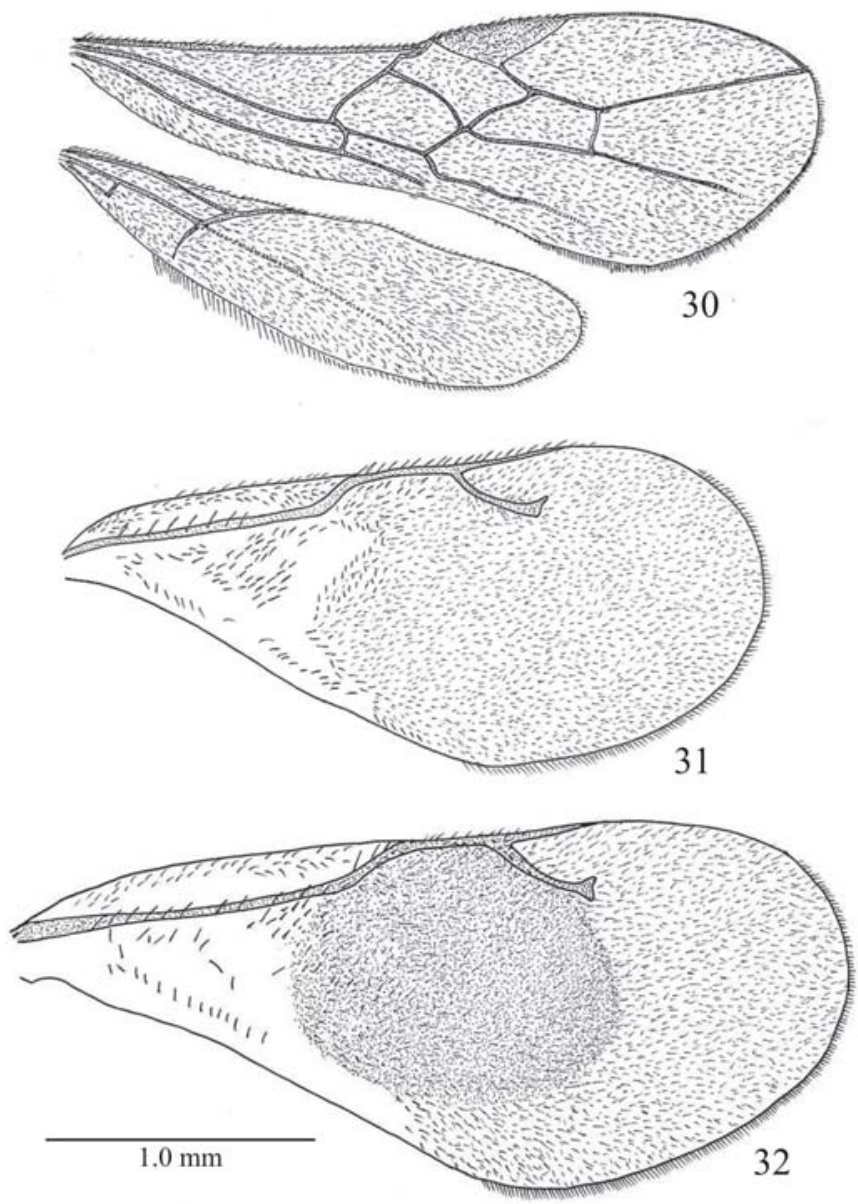

Figs. 30-32. Allorhogas taua sp.nov., female, 30, wings. Tanaostigmodes ringueleti, 31, fore wing. Tanaostigmodes mecanga sp. nov., 32, fore wing.

than wide, as long as the second; marginal fringe past the apex of fore wing; basal cell with at least 22 setae. Wings hyaline with large spot light brown on its median area.
Acknowledgments. We are grateful to Conselho Nacional de Desenvolvimento Científico e Tecnológico, (CNPq), Fundação de Amparo à Pesquisa do Estado de São Paulo (FAPESP) for financial support and to Paul. M. Marsh for reviewing the manuscript.

\section{REFERENCES}

Capek, M. 1970. A new classification of the Braconidae (Hymenoptera) based on the cephalic structures of the final instar larva and biological evidence. Canadian Entomologist 102: 846-875.

Hanson, P. E. 1995. Eurytomidae, p. 336-342. In: P. Hanson \& I. D Gauld (eds). The Hymenoptera of Costa Rica. Oxfor University Press, $\mathrm{xx}+893 \mathrm{p}$.

LaSalle, J. 1987. New World Tanaostigmatidae (Hymenoptera, Chalcidoidea). Contributions of the American Entomological Institute 23: 1-181.

Lorenzi, H. \& H. M. De Souza. 1999. Plantas ornamentais no Brasil. Arbustivas, herbáceas e trepadeiras. Instituto Plantarum de Estudos da Flora Ltda. 1088 p.

Macedo, M. V. \& R. T. Monteiro. 1989. Seed predation by a braconid wasp Allorhogas sp. (Hymenoptera). Journal of the New York Entomological Society 97: 358-362.

Marsh, P. M. 1991. Description of a phytophagous doryctine braconid from Brazil (Hymenoptera: Braconidae). Proceedings of Entomological Society of Washington 93: 92-95.

Marsh, P. M. 1997. Subfamily Doryctinae, p. 206-233. In: R. A. Wharton et al. (ed.). Manual of the New World Genera of the family Braconidae (Hymenoptera), Special Publication of the International Society of Hymenopterists, no. 1, 439 p.

Marsh, P. M. 2002. The Doryctinae of Costa Rica (excluding the genus Heterospilus). Memoirs of the American Entomological Institute 70: 1-319.

Marsh, P. M.; M. V. Macedo \& M. C. P. Pimentel. 2000. Descriptions and biological notes on two new phytophagous species of the genus Allorhogas from Brazil (Hymenoptera: Braconidae: Doryctinae). Journal of Hymenoptera Research 9: 292-297.

Perioto, N. W. \& R. I. R. Lara. 2005. Duas novas espécies de Tanaostigmodes Ashmead, 1896 (Hymenoptera, Tanaostigmatidae) obtidas de galhas de Calliandra dysantha Benth (Leguminosae, Mimosoidea) do Brasil Central. Biota Neotropica 5: 1-11.

Received 06/02/2007; accepted 21/03/2008 